\title{
Contributors to This Issue
}

RosAmUND JOHNSTON is a postdoctoral fellow at the University of Vienna's Research Center for the History of Transformations (RECET, Spitalgasse 2/ Hof 1.1, Campus, 1090 Wien, Germany; email: rosamund.johnston@univie.ac.at). She is the author of Havelv Americe (2019). Her current research maps the global history of socialist Czechoslovakia through its arms trade.

Mark T. Kettler is a Postdoctoral Research Associate of the Nanovic Institute for European Studies (University of Notre Dame, Notre Dame, IN 46556, USA; email: mkettler@nd.edu). A historian of Germany and East-Central Europe, he studies imperialism and colonialism to analyze larger questions of national identity and the relationship of ethnic minorities to the modern state. His current book project, provisionally entitled The Knight, Death, and the Devil, argues that the German occupation of Russian Poland in WWI fundamentally transformed how German military, political, and intellectual elites understood the relationship between ethnic diversity and imperial stability. Mark received his $\mathrm{PhD}$ in history from the University of California, Berkeley, in 2018. He is author of "Designing Empire for the Civilized East: Colonialism, Polish Nationhood, and German War Aims in the First World War" (Nationalities Papers, 2019), and "What did Paul Rohrbach Actually Learn in Africa?: The Influence of Colonial Experience on a Publicist's Imperial Fantasies in Eastern Europe" (German History, 2020).

William L. Patch earned his PhD in German history at Yale University in 1981 and has taught history at Grinnell College and at Washington and Lee University since 2005 (Washington and Lee University, 204 West Washington Street, Lexington, VA 24450, USA; email: patchw@wlu. edu). He has published the monographs The Christian Trade Unions in the Weimar Republic, Heinrich Brüning and the Dissolution of the Weimar Republic, and Christian Democratic Workers and the Forging of German Democracy, 1920-1980. 


\section{FORTHCOMING}

Volume $55 \quad$ Number 1

2022

\section{Special Issue: Sovereignty in German History}

Guest Editors: Heidi Tworek and Rüdiger Graf

Featured Essay: The Present Is History

Rethinking Central Europe as a Migration Space: From the Ottoman Empire through the Cold War and the Refugee Crisis

Michelle Kahn

Articles

Negotiating Sovereignty in German History-Historiographical Challenges

Rüdiger Graf and Heidi Tworek

Buying Sovereignty: German 'Weltpolitik' and Private Enterprise, 1884-1914 Steven Press

Transitional Injustice at Leipzig: Negotiating Sovereignty and International Humanitarian Law in Germany after the First World War Rüdiger Graf

Sovereignty Trade-Offs between Politics and the Economy: The Deconcentration of IG Farben after 1945

Philipp Müller

Dividing the Indivisible: The German Question, National Division, and the United

Nations during the Cold War Sebastian Gehrig

"Pathological Gamblers" and "Sovereign Consumers": National Gambling

Regulation and the Challenges of European Integration and Digitization

in Germany, 2004-2018

Laura Kaiser

Afterword: The Long Shadow of Jean Bodin

Helmut Walser Smith

Book Reviews 


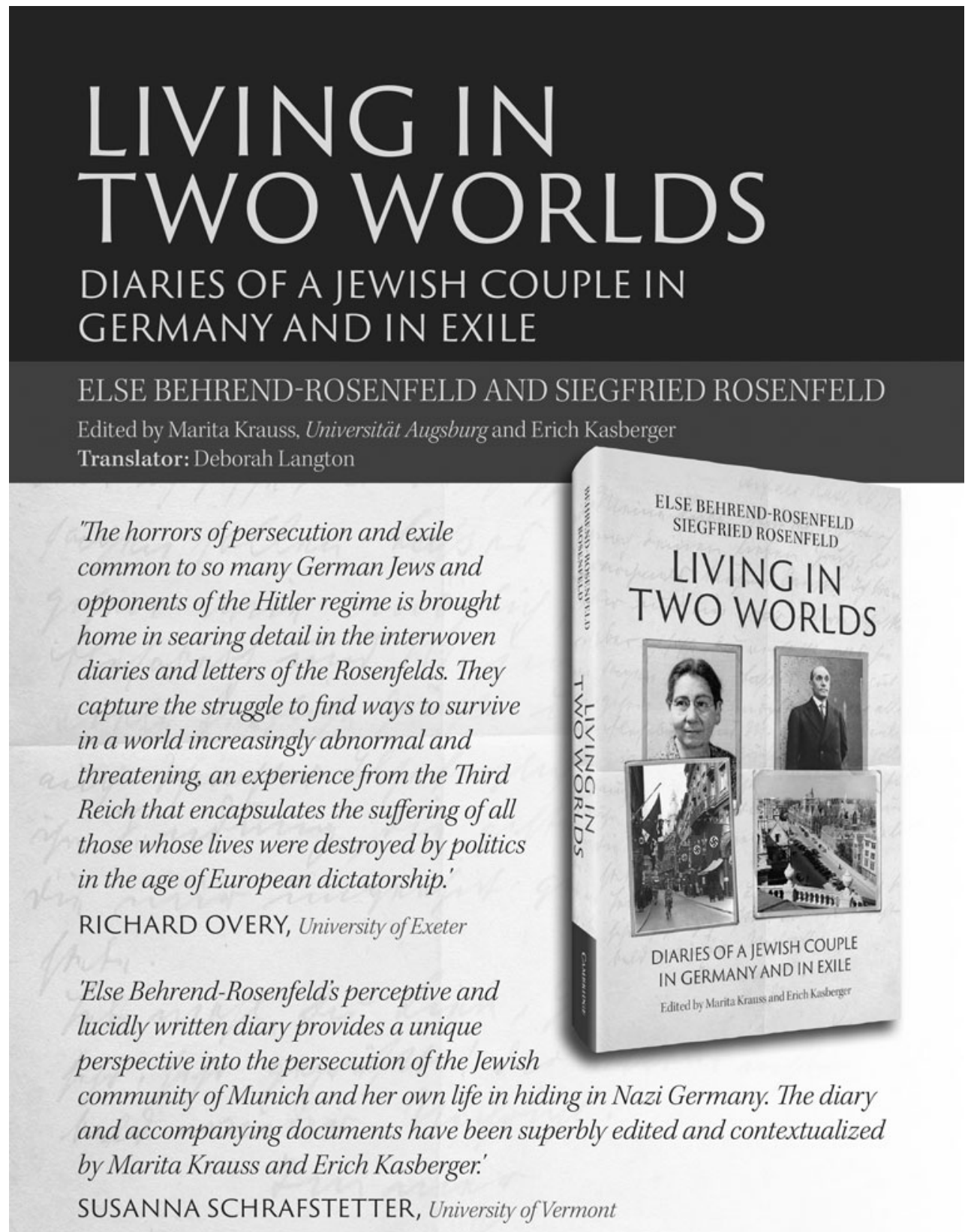

@cambUP_History

Hardback ISBN: 9781316519097

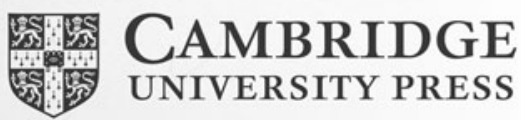




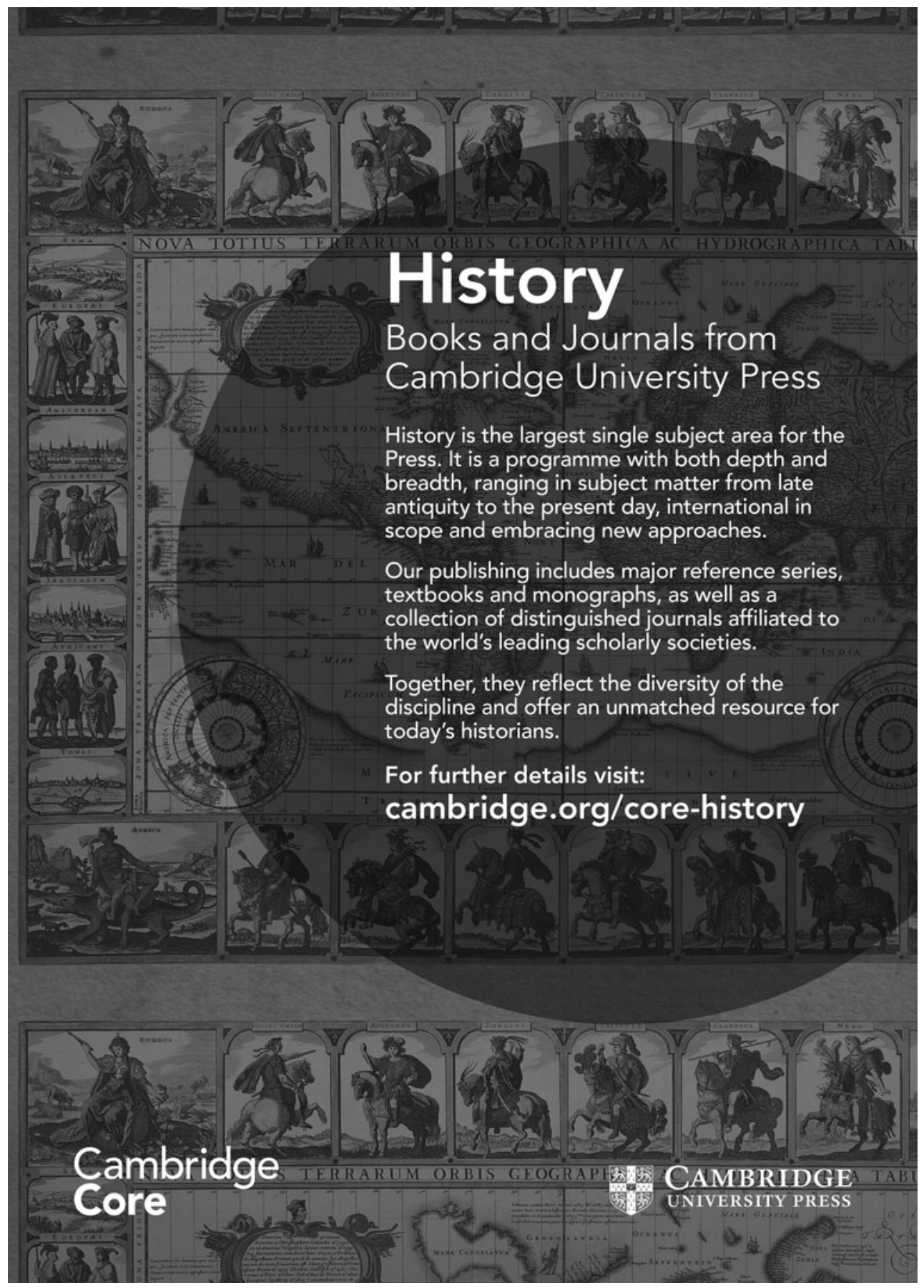


Published since 1968, Central European History is the primary venue for scholarly exchange and debate of central Europe's diverse and complex history. The journal publishes on a range of topics, bringing research articles, book and film reviews and review essays, discussion fora, and other forms of scholarly writing to a broad audience of specialists and non-specialists in four issues per year. Spanning the medieval to the modern period, CEH offers a space for creative approaches to understanding the region's past, while continually reassessing its conceptual and geographic boundaries and their representations. $\mathrm{CEH}$ publishes work related to German-speaking and German-identified peoples, as well as work on non-German-speakers in the historic states and regions of central Europe, including the Habsburg lands, Austria, and Switzerland. The journal welcomes submissions that expand and de-territorialize the region's historic frames of reference, taking identity, language, and space — and the complex links and ruptures among them—seriously. CEH perennially engages anew the old question, "what and where is central Europe?"

\section{Editorial Policy}

Central European History welcomes manuscripts using all approaches to history and dealing with all historical periods. Because space is limited, the journal does not accept articles that have been or will be published elsewhere. Most research articles are 10-12,000 words, including notes. Manuscripts submitted to Central European History should not be under consideration by any other journal. If the Editor learns that an article Central European History is considering is also under submission at another journal, Central European History's consideration will cease. Book Reviews range from 800-1000 words and are commissioned by the Associate Editor. Unsolicited book reviews are not accepted. Authors may submit articles in languages other than English but only after consulting the Editor. Some financial support may be available to defray the costs of translation into English if a manuscript is accepted.

All article manuscripts should be submitted via ScholarOne (https://mc. manuscript- central. $\mathrm{com} / \mathrm{ccc})$. Authors should please take care to remove any information that might identify them as author, and follow the prompts in ScholarOne to make their manuscripts anonymous. The entire text of all manuscripts, including footnotes and headings, must be prepared in double-spaced typescript with generous margins to allow for copyediting. Footnotes must be numbered consecutively.

All materials will be edited to conform with The Chicago Manual of Style in matters of punctuation, capitalization, and format. Final decisions on style remain with the editor.

Correspondence for the editor should be sent to:

E-mail: ceh@utk.edu,or

\section{The Editor, Central European History}

University of Tennessee, Knoxville

Department of History

Dunford Hall, 6th Floor

Knoxville, TN 37996

USA

Correspondence for the associate editor, book reviews should be sent to:

E-mail: ceh@ohio.edu, or

The Associate Editor, Central European History

Department of History

421 Bentley Annex

Ohio University

Athens, $\mathrm{OH} 45701$

USA 


\section{CENTRAL EUROPEAN HISTORY}

Volume 54 | Number 4 | December 2021

\section{ARTICLES}

Listening in on the Neighbors: The Reception of German and Austrian Radio in Cold War

Czechoslovakia

Rosamund Johnston

"Incurable Megalomania" and "Fantasies of Expansion": The German Army Reimagines

Empire in Occupied Poland, 1915-1918

Mark T. Kettler

Defending the "Peace of Sunday": The Debate over Sunday Labor in the West German

Steel Industry after the Second World War

William L. Patch

\section{ESSAY FORUM}

Central European History in the Age of COVID-19

Christian Goeschel, Dominique Reill, and Lucy Riall, guest editors

BOOK REVIEWS

CONTRIBUTORS TO THIS ISSUE

FORTHCOMING

\section{Cambridge Core}

